The EU-Ukraine Association Agreement: A New Legal Instrument of Integration Without Membership?

Authors: Roman Petrov, Guillaume Van der Loo, Peter Van Elsuwege

Source: Kyiv-Mohyla Law and Politics Journal 1 (2015): 1-19

Published by: National University of Kyiv-Mohyla Academy

http://kmlpj.ukma.edu.ua/ 


\title{
The EU-Ukraine Association Agreement: A New Legal Instrument of Integration Without Membership?
}

\author{
Roman Petrov \\ National University of Kyiv-Mohyla Academy, \\ Department of International Law, \\ Jean Monnet Centre of Excellence
}

\section{Guillaume Van der Loo}

Ghent University

\section{Peter Van Elsuwege}

Ghent University,

Ghent European Law Institute

\begin{abstract}
This article analyses the EU-Ukraine Association Agreement (EU-Ukraine AA). It argues that this new legal framework, which has the objective to establish a unique form of political association and economic integration, is characterized by three specific features: comprehensiveness, complexity and conditionality. After a brief background of the EU-Ukraine relations, the following aspects are scrutinized: legal basis and objectives, institutional framework and mechanisms of enhanced conditionality, and legislative approximation. In addition, constitutional challenges for the effective implementation of the EU-Ukraine AA are discussed. Based upon a comparison with other EU external agreements, it is demonstrated that the EU-Ukraine AA is an innovative legal instrument providing for a new type of integration without membership.
\end{abstract}

Key Words: European Union, Ukraine, Association Agreement, Deep and Comprehensive Free Trade Area, integration, legislative approximation.

\section{Introduction}

"We are here to sign the Association Agreements between the European Union and each of your countries. These are not just any other agreements - but milestones in the history of our relations and for Europe as a whole. In Kiev and elsewhere, people gave their lives for this closer link to the European Union. We will not forget them."1

$1 \quad$ European Council, "Statement at the Signing Ceremony of the Association Agreements with Georgia, Republic of Moldova and Ukraine," Brussels, 27 June 2014, EUCO 137/14, accessed August 30, 2015, http://www.consilium.europa.eu/uedocs/cms_data/docs/pressdata/en/ec/143415.pdf. 
This statement of the President of the European Council was made on 27 June 2014 at the signing ceremony of the bilateral Association Agreements (AAs) between the European Union (EU) and Ukraine, Moldova and Georgia. This new generation of AAs will replace the outdated Partnership and Cooperation Agreements (PCAs) as the basic legal framework for the bilateral relations between the EU and those countries.

According to Herman Van Rompuy, the EU-Ukraine AA — which served to a large extent as a template for the agreements with Moldova and Georgia - is "the most advanced agreement of its kind ever negotiated by the European Union."2 A cursory reading of the agreement, counting around 2,140 pages in the Official Journal including 46 annexes, 3 protocols and a joint declaration, already reveals that it is unprecedented both in terms of scope and level of detail. ${ }^{3}$ The agreement essentially aims to deepen the political and economic relations between Ukraine and the EU through the establishment of an enhanced institutional framework and innovative provisions on regulatory and legislative approximation. Of particular significance is the ambition to set up a Deep and Comprehensive Free Trade Area (DCFTA), leading to "Ukraine's gradual integration in the EU internal market."4 Accordingly, the EU-Ukraine AA belongs to the selected group of "integration-oriented agreements", i.e., agreements including principles, concepts and provisions of EU law that are to be interpreted and applied as if the third State is part of the EU. ${ }^{5}$ Such agreements are an exceptional phenomenon in the practice of the EU's external action. Apart from the well-known multilateral examples of the European Economic Area (EEA) agreement, the Energy Community Treaty (EnC Treaty) and the European Common Aviation Area (ECAA) agreement, a limited number of specific bilateral agreements also deserve this qualification.

It will be argued that the EU-Ukraine AA is unique in many respects and, therefore, provides a new type of integration without membership. ${ }^{6}$ The Agreement can be characterized by three specific features: comprehensiveness, complexity and conditionality.

2 European Council, Press Remarks by H. Van Rompuy, President of the European Council, following the EU-Ukraine Summit, Brussels, 25 February 2013, EUCO 48/13, accessed August 30, 2015, http://europa.eu/rapid/press-release_PRES-13-74_en.htm.

3 Association Agreement between the European Union and its Member States, of the one part, and Ukraine of the other part, $O J, 2014, \mathrm{~L} 161 / 3$.

The explicit reference to "Ukraine's gradual integration in the EU Internal Market" as one of the EU-Ukraine AA's objectives (Art. $1(\mathrm{~d})$ ) is quite remarkable. In comparison, the Euro-Mediterranean Association Agreements (EMAAs) and pre-accession instruments such as the Stabilisation and Association Agreements (SAAs) with the Western Balkan countries do not include such a reference in their corresponding articles. For example, the objectives of the SAAs only aim "to promote harmonious economic relations and develop gradually a free trade area” (Art. 1(1)(f) EU-Serbia SAA, $O J, 2010, \mathrm{~L} 28 / 2$ ). The EMAAs aim to "establish the conditions for the gradual liberalisation of trade in goods, services and capital" (Art. 1(2) EU-Morocco EMAA, OJ, 2000, L 70/2).

5 The expression “integration-oriented agreements" is borrowed from Marc Maresceau. See: Marc Maresceau, “Les accords d'intégration dans les relations de proximité de l'Union européenne," in Les frontières de l'Union européenne, ed. Claude Blumann (Bruxelles: Bruylant, 2013), 151-92.

6 Adam Łazowski, "Enhanced Multilateralism and Enhanced Bilateralism: Integration without Membership in the European Union," Common Market Law Review 45.5 (2008). 
First, the EU-Ukraine AA is a comprehensive framework agreement covering the entire spectrum of EU-Ukraine relations. Hence, it includes provisions dealing with the whole array of EU activities, including cooperation and convergence in the field of common foreign and security policy (CFSP) as well as cooperation in the area of freedom, security and justice (AFSJ). ${ }^{7}$ Moreover, due to the inclusion of provisions on nuclear energy and areas falling within Member State competences, the European Atomic Energy Community (Euratom) and all EU Member States are also contracting parties to the agreement. Whereas the Treaty of Lisbon significantly facilitates the conclusion of what used to be called "cross-pillar agreements," the comprehensive scope of the Agreement necessarily generates a certain complexity. For instance, the EUUkraine AA provisions dealing with the AFSJ do not bind the United Kingdom and Ireland as EU Member States as a result of the "opt-out" granted under Protocol 21 to the EU Treaties. Yet, those countries are bound as separate contracting parties due to the mixed nature of the agreement and can decide to "opt in" as part of the EU after notifying Ukraine. A specific regime also applies to Denmark, in accordance with Protocol 22 to the EU Treaties. The comprehensive scope of the EU-Ukraine AA also implies that in certain areas of cooperation there is an overlap with existing agreements and obligations. Pursuant to Article 479 of the EU-Ukraine AA, such (existing) agreements "shall be considered part of the overall bilateral relations as governed by this Agreement and as forming part of a common institutional framework." As a result, the Agreement includes various provisions clarifying the relationship with other bilateral and multilateral agreements aiming to ensure a coherent legal framework for EU-Ukraine relations. This, too, contributes to the complexity of the Agreement.

Second, the complexity of the EU-Ukraine AA is not only related to its comprehensive scope but also to its level of ambition, in particular the aim to achieve Ukraine's economic integration in the EU internal market through the establishment of a DCFTA. The objective of "deep" integration requires extensive legislative and regulatory approximation including sophisticated mechanisms to secure the uniform interpretation and effective implementation of relevant EU legislation.

Last but not least, the EU-Ukraine AA is based on a strict conditionality approach. The preamble to the agreement explicitly states that "political association and economic integration of Ukraine within the European Union will depend on progress in the implementation of the current agreement as well as Ukraine's track record in ensuring respect for common values, and progress in achieving convergence with the EU in political, economic and legal areas." This link between the third country's performance and the deepening of the EU's engagement is a key characteristic of the European Neighborhood Policy (ENP) and the Eastern Partnership (EaP). Whereas this principle has so far been applied on the basis of soft-law instruments such as Action Plans and the Association Agenda, it is now encapsulated in a legally binding bilateral agreement.

Guillaume Van der Loo, "The EU-Ukraine Deep and Comprehensive Free Trade Area: A Coherent Mechanism for Legislative Approximation?" in Legislative Approximation and Application of EU Law in the Eastern Neighbourhood of the European Union. Towards a Common Regulatory Space? eds. Peter Van Elsuwege and Roman Petrov (Milton Park, Abingdon, Oxon: Routledge, 2014), 63-88. 
In what follows, the specific features of the EU-Ukraine AA are analyzed in more detail in order to illustrate that the agreement opens a new chapter in the EU's relations with its neighboring countries and, more generally, in its external relations practice. After a brief introduction to the background of the new EU-Ukraine AA, its legal basis and objectives are discussed. Subsequently, specific attention is devoted to the institutional framework and mechanisms of conditionality. A final section deals with the constitutional challenges for the effective implementation of the EU-Ukraine AA.

\section{Background of EU-Ukraine Relations: From Partnership and Cooperation to Association}

The EU-Ukraine AA will replace the Partnership and Cooperation Agreement (PCA) as the basic legal framework of EU-Ukraine relations. ${ }^{9}$ The PCA, which was signed in 1994, entered into force in March 1998 for an initial period of ten years. ${ }^{10}$ Pursuant to its Article 101, the agreement is automatically extended each year unless either side informs the other party of its denunciation at least six months before the expiry date. Whereas, from a legal point of view, the PCA could therefore continue to apply without formal problems, a revision of the legal framework was urgently needed.1 ${ }^{11}$ Due to internal developments in both the EU and Ukraine, several provisions of the PCA are out of date and no longer reflect the current ambition of the bilateral relationship. The preamble and Article 1, for instance, refer to Ukraine as "a country with an economy in transition," which is no longer appropriate after the country's accession to the World Trade Organization (WTO) in 2008.

Moreover, the agreement includes general and broadly defined provisions on economic co-operation ${ }^{12}$ but stops short of any regional trade integration. Article 4 PCA only provides that the parties consider "whether circumstances allow the beginning of negotiations on the establishment of a free trade area."13 Like many other provisions of the agreement, this so-called "evolutionary clause" is essentially a declaration of intent without any direct legal consequences.

The minimalistic approach of the PCA is particularly well-illustrated as regards the objective of approximating Ukraine's existing and future legislation to that of the EU. While recognizing that this process of legislative approximation is an important condition for strengthening the economic links between the parties, Article $5_{1}$ PCA proclaims that Ukraine "shall endeavour

$9 \quad$ Art. 479 EU-Ukraine AA.

10 Council and Commission Decision of 26 January 1998 on the conclusion of the PCA between the EC and their Member States and Ukraine, OJ, 1998, L 49.

11 A similar reasoning applies for the PCAs with Russia, Moldova, Georgia, Armenia and Azerbaijan. With Belarus, a PCA was signed in 1995 but never entered into force due to political reasons.

12 The title "Economic Cooperation" in the PCA contains provisions on industrial cooperation, investment promotion and protection, public procurement, co-operation in the field of standards and conformity assessment, education and training, energy, environment, cooperation in science and technology, tourism, monetary policy, social cooperation, money laundering, regional development, information and communication, statistical cooperation, etc. 
to ensure that its legislation be gradually made compatible with that of the Community [now Union]." ${ }^{14}$ This can hardly be regarded as a formal legal commitment. Its vague and open-ended formulation gave the Ukrainian authorities a considerable freedom to define the time-schedule and methods of implementation. There is only an obligation to act but without a requirement to achieve particular results or a sanction in case the approximation of laws obligation is not fulfilled. Moreover, the approximation clause includes a long list of "priority areas" for legislative action ${ }^{15}$ but fails to provide clear guidelines on the scope and content of the EU laws to be taken as the basis for approximation. Nor does it include a link with the objective to establish a Free Trade Area (FTA) in the future. ${ }^{16}$

The launch of the ENP in the wake of the EU's eastward enlargement provided new impetus to EU-Ukraine relations. In this context, the European Commission proposed to move beyond mere cooperation to a significant degree of economic integration in return for concrete progress in terms of legal approximation. ${ }^{17}$ In the short term, an ENP Action Plan — adopted with Ukraine in 2005 for a period of three years - laid down political and economic priorities for reform whereas the negotiation of a new bilateral framework agreement to replace the PCA was considered to be a long term objective. ${ }^{18}$ At the end of 2006, the Commission announced its intention to negotiate "deep and comprehensive free trade agreements" (DCFTAs) with the EU's neighbors including "substantially all trade in goods and services" and "strong legally-binding provisions on trade and economic regulatory issues."19

Against the political background of the Orange Revolution, Ukraine was the first ENP country to start negotiations on a new Association Agreement in March 2007 as part of a general revision of the bilateral legal framework. Negotiations on the DCFTA were only launched in February 2008 after Ukraine's accession to the WTO. A political agreement was reached in December 2011 and the EU-Ukraine AA was initialed in March 2012. ${ }^{20}$ On 15 May 2013, the Commission adopted the proposals for a Council Decision on the signing and conclusion of

14 Art. $5^{1}$ EU-Ukraine PCA, emphasis added.

15 Art. 51(2) EU-Ukraine PCA refers to customs law, banking law, company accounts and taxes, intellectual property, protection of workers at the workplace, financial services, rules on competition, public procurement, protection of health and life of humans, animals and plants, the environment, consumer protection, indirect taxation, technical rules and standards, nuclear laws and transport. Roman Petrov, "Recent Developments in the Adaptation of Ukrainian Legislation to EU Law," European Foreign Affairs Review 8.1 (2003): 131.

17 European Commission, "Wider Europe-Neighbourhood: A New Framework for Relations with our Eastern and Southern Neighbours," COM (2003) 104 final, 11 March 2003.

18 In November 2009, the EU-Ukraine Action Plan was replaced by a bilateral Association Agenda (EU-Ukraine Cooperation Council, "Recommendation on the implementation of the EU-Ukraine Association Agenda to prepare and facilitate the implementation of the Association Agreement," UE-UA 1057/og23, 23 November 2009).

19 European Commission, "Communication from the Commission to the Council and the European Parliament on Strengthening the European Neighbourhood Policy," COM (2006) 726 final, 4 December 2006, 4. 
the EU-Ukraine AA. ${ }^{21}$ Nevertheless, this agreement was not immediately signed due to demands on behalf of the EU to abandon the practice of selective justice and to align the Ukrainian judiciary and law enforcement systems with European standards..$^{22}$ Eventually, on the eve of the EaP Summit in Vilnius, the Ukrainian Government decided to suspend the process of preparation for signature of the EU-Ukraine AA in order "to ensure the national security of Ukraine and to recover trade and economic relations with the Russian Federation."23 Following this news, hundreds of thousands of Ukrainians went to the streets. The ensuing Euromaidan Revolution led to the dismissal of President Viktor Yanukovych on 22 February 2014 and the establishment of an Interim Government under the leadership of Arseniy Yatsenyuk. Proceeding with the signature of the EU-Ukraine AA was a clear short-term objective for the new authorities in Kyiv. ${ }^{24}$

Despite the political pressure to act quickly, this was not an evident option. Under the Ukrainian Constitution, the President is responsible for the signature of international agreements. ${ }^{25}$ After the escape of Viktor Yanukovych, Ukraine only had an acting President Oleksandr Turchynov, who had been appointed by the Parliament without an election. Taking into account the legal and political significance of the EU-Ukraine AA, including long-term and far-reaching commitments of legislative approximation with the EU, this clearly raised some questions of legitimacy. At the same time, there was also a growing understanding that a clear message of solidarity to the Ukrainian people was needed in light of the mounting Russian pressure on Crimea and the Eastern part of Ukraine. In this context, the EU Heads of State or Government announced on 6 March 2014 that "as a matter of priority" all the political chapters of the EU-Ukraine AA would be signed first. In addition, the adoption of autonomous trade measures "would allow Ukraine to benefit substantially from the advantages offered in the Deep and Comprehensive Free Trade Area." ${ }^{26}$ The signature of the political provisions of

21 European Commission, "Signature of Association Agreement with the EU will Depend on Ukraine's Performance," Press Release, May 15, 2013, IP/13/436.

22 3209th Foreign Affairs Council Meeting, Council Conclusions on Ukraine, 1o December 2012.

23 Decision of the Cabinet of Ministers of Ukraine from 21 November 2013, No. 905-p. Arguably, the Ukrainian government's decision cannot be disconnected from the Russian proposal to establish a Eurasian Union building upon the already existing customs union between Russia, Belarus and Kazakhstan. On the background of this initiative and its implications for EU-Ukraine relations, see: Peter van Elsuwege and Guillaume Van der Loo, "Competing Paths of Regional Economic Integration in the Post-Soviet Space: Legal and Political Dilemmas for Ukraine," Review of Central and East European Law 37 (2012): 421-47.

24 Georgi Gotev, “Ukraine Ready to Sign Association Agreement during March EU Summit," Euractiv. com, February 27, 2014, accessed December 30, 2014, http://www.euractiv.com/europes-east/ukrainewants-sign-association-a-news- 533818. Art. 106(3) of the Ukrainian Constitution.

26 Statement of the Heads of State or Government on Ukraine, Brussels, 6 March 2014, accessed December 30, 2014, http://www.consilium.europa.eu/uedocs/cms_data/docs/pressdata/en/ ec/141372.pdf. 
the EU-Ukraine AA effectively took place on 21 March $2014{ }^{27}$ and on 14 April 2014, after a "fast track" approval process, the European Parliament and the Council adopted a Regulation "on the reduction or elimination of customs duties on goods originating in Ukraine." 28 Accordingly, Ukraine can benefit from the EU's unilateral trade preferences in accordance with the schedule of concessions set out in annex I-A of the EU-Ukraine AA in anticipation of the (provisional) application of the entire agreement. ${ }^{29}$

It is noteworthy that the political and economic parts of the EU-Ukraine AA remain part of a single legal instrument. ${ }^{30}$ In other words, the partial signature of the agreement on 21 March 2014 may essentially be regarded as a political gesture underlining the parties' commitment to shared values and the objectives of the envisaged association. The direct legal implications are fairly limited because the political provisions are rather general in nature. In addition to a list of general principles underlying the bilateral relationship, they include the establishment of a multi-level political dialogue and convergence in the field of CFSP. Moreover, this partial signature did not result in the entry into force of these "political" chapters, neither to their provisional application. It was only after the final signature of the entire agreement on 27 June 2014 by the newly elected President Petro Poroshenko that the ratification procedure for the

27 The "political provisions" of the agreement which were signed on 21 March 2014 include the preamble, Article 1 (objectives), Title I (general principles), II (political dialogue and reform, political association cooperation and convergence in the field of CFSP) and VII (institutional, general and final provisions). See: Final Act of the Summit between the EU and its Member States, of the one part, and Ukraine, of the other part, as regards the Association Agreement, accessed December 30 , 2014, http://eeas.europa.eu/delegations/ukraine/documents/association_agreement/final_act_text_ en.pdf $>$. It must be noted that Title III (justice, freedom and security) can also be considered as a "political chapter" of the AA. However, several Member States opposed the signature of this chapter on 21 March 2014 as it includes "sensitive" provisions on treatment and mobility of workers and movement of persons (Arts. 17-19) (Interview with EEAS official, 22 April 2014). Regulation (EU) No. 374/2014 of the European Parliament and of the Council of 16 April 2014 on the reduction or elimination of customs duties on goods originating in Ukraine (OJ, 2014, L 118/1). The unilateral trade preferences apply until the DCFTA part of the EU-Ukraine AA (provisionally) enters into force and in any case no later than 1 November 2014. It is noteworthy that the EU did not request a WTO waiver for the adoption of the autonomous measures (under Art. IX:3 WTO) because they anticipate the (provisional) application of the EU-Ukraine DCFTA. Hence, the EU's démarche is deemed to be in conformity with GATT Article XXIV. See, on the development of this line of argumentation, the response of the Commission's representative to questions during the meeting of the European Parliament Committee on International Trade (INTA), Brussels, 19-20 March, accessed December 30, 2014, http://www.parlament.gv.at/PAKT/EU/XXV/EU/o1/82/EU_18238/ imfname_10451522.pdf.

30 Final Act of the Summit between the EU and its Member States, of the one part, and Ukraine, of the other part, as regards the Association Agreement, accessed December 30, 2014, http://eeas.europa. eu/delegations/ukraine/documents/association_agreement/final_act_text_en.pdf. 
entire agreement could be initiated. ${ }^{31}$ Because the EU-Ukraine AA is a mixed agreement, which needs to be ratified by all $28 \mathrm{EU}$ Member States, this procedure can take several years. In order to circumvent this long ratification procedure, Article 486 of the EU-Ukraine AA provides for the possibility of the provisional application of the agreement. Given the political significance of the EU-Ukraine AA, the Council agreed on an exceptionally wide scope for provisional application, including, inter alia, the entire title on General Principles (Title I) and Financial Cooperation (Title VI), almost the entire DCFTA (Title IV), Institutional, General and Final Provisions (Title VII) and several provisions regarding political dialogue (Arts. 4-6), Justice, Freedom and Security (Arts. 14 and 19) and economic and sectoral cooperation. This broad scope could raise questions on the provisional application of "mixed" elements of the EUUkraine AA. The Council Decisions state that on the signing of the Agreement that these listed provisions shall be applied on a provisional basis "only to the extent that they cover matters falling within the Union's competence, including matters falling within the Union's competence to define and implement a common foreign and security policy."32 In addition, the Council, Commission and High Representative adopted a Joint Statement providing that the provisional application of the General Principles set down in Article 2 "is without prejudice to the division of competences between the Union and the Member States on the matters referred to therein."

\section{Legal Basis and Objectives}

The comprehensive and complex nature of the EU-Ukraine AA is reflected in the choice of its legal basis. The Council Decision on the signing and provisional application of the political provisions, adopted on 17 March 2014, combines the legal basis for EU action in the area of CFSP (Arts. 31(1) and 37 Treaty on the EU (TEU)) with the traditional provision on association (Art. 217 Treaty on the Functioning of the EU (TFEU)). ${ }^{33}$ From a procedural point of view, the presence of a CFSP legal basis does not make a major difference because association agreements already require unanimity in the Council. ${ }^{34}$ Moreover, the CFSP dimension of the EU-Ukraine AA is too limited to overrule Art. 218(6)a(i) TFEU which requires the consent of the European Parliament for the conclusion of association agreements. ${ }^{35}$ Nevertheless, the combination of CFSP/TFEU

31 The simultaneous ratification of the Association Agreement by Ukrainian Parliament and the European Parliament took place on 16 September 2014. Meanwhile the EU-Ukraine AA is under lengthy process of ratification by parliaments of the EU Member States. Therefore the interim application of the association agreements is taking place in accordance with the EU Council decisions (Council Decision 2014/295/EU of 17 March 2014 and COM(2014)6o9). Application of Title IV (deep and comprehensive free trade area) of the EU-Ukraine Association Agreement has been postponed till 1 January 2016 due to political and security pressure of the Russian Federation.

See Art. 4 Council Decision 2014/295/EU.

See Art. 4 Council Decision 2014/295/EU.

Art. 218(8) TFEU.

According to Art. 218(6) TFEU, an association agreement can only be concluded without the consent of the European Parliament if it relates "exclusively" to CFSP. In recent Case C-658/11, Commission v. Council, the Court of Justice clarified that the substantive legal basis of a Council decision adopted 
legal bases may be regarded as a logical consequence of the continuing bipolarity of the EU's external action as reflected in Article 40 TEU. The EU-Ukraine AA is one of the first examples of this new practice, which stems from the Lisbon Treaty amendments to the procedural code for negotiating and concluding international agreements on behalf of the EU. ${ }^{36}$

A more controversial question concerned the adoption of two separate Council Decisions for the signature and provisional application of the remaining titles of the EU-Ukraine AA on 27 June 2014. ${ }^{37}$ Despite the Commission's proposal for a single decision on the basis of Article 217 TFEU, the Council opted to "split off" the provisions relating to the treatment of third-country nationals legally employed as workers in the territory of the parties (Art. 17 EUUkraine AA). The latter formed the subject of a separate Council Decision adopted on the basis of Article 79(2)(b) TFEU. The main reason for this complexity is the specific status of the United Kingdom and Ireland in respect to the EU competences in the Area of Freedom Security and Justice (AFSJ). Pursuant to Protocol 21 to the Treaty of Lisbon, both countries have the discretionary power to decide whether or not they want to take part in the adoption of legislative acts under this title. ${ }^{38}$ Taking into account that Article 17 of the EU-Ukraine AA falls within the scope of the AFSJ, in particular Article 79(2)(b) TFEU on the rights of third-country nationals residing legally in the EU Member States, a separate Council Decision was deemend necessary. Nevertheless, this option is not undisputable. Article 17 EU-Ukraine AA is an integral part of the estabished association and it seems far-fetched to argue that the aim and content of this provision is distinct from and independent of the aim and content of the other provisions of the EU-Ukraine AA. Moreover, in its recent judgment in Commissionv. Council (Case C-377/12), the Court of Justice of the EU (Court of Justice) considered the addition of specific legal bases relating to readmission of third-country nationals (Art. 79(3) TFEU), transport (Arts 91 and 100 TFEU) and environment (Art. 191(4) TFEU) unnecessary and unlawful for the signature of a Framework Agreement on Partnership and Cooperation between the EU and the Republic of the Philippines. ${ }^{39}$ In the Court's view, the broad scope of Articles 207 and 209 TFEU dealing, respectively, with common commercial policy and development cooperation was sufficient to cover the entire agreement. Of course, the context and the objectives of the EU-Ukraine AA are entirely different. Nevertheless, the argument may be made that Article 217 TFEU on association is a "catch-all" provision, which does not require the adoption of a separate Council decision related to one specific provision of the agreement. This interpretation was not only

for the conclusion of an international agreement determines the procedures to followed. Hence, only when the substantive legal basis exclusively relates to the area of CFSP, the European Parliament does not play a role in this process. The unified procedure for the negotiation and conclusion of international agreements on behalf of the EU is laid down in Art. 218 TFEU.

This concerns Title III (freedom, security and justice), IV (trade and trade-related matters), $\mathrm{V}$ (economic and sector cooperation) and VI (financial cooperation with anti-fraud provisions). Protocol (No. 21) on the position of the United Kingdom and Ireland in respect of the area of freedom, security and justice, OJ, 2010, C83/295. 
strongly supported by the European Commission ${ }^{40}$ but also by several Member States. Taking into account the political importance of the EU-Ukraine AA, it seems unlikely that the final decision to use a "split" legal basis will be challenged before the Court of Justice.

The conclusion of association agreements with European countries is often perceived as a stepping-stone towards EU membership. For example, after the signing ceremony on 27 June 2014, the heads of State or Government of the three associated countries linked the conclusion of the AAs with their (long-term) EU membership aspirations. However, there is no automatic link between association and accession prospects. The EU-Ukraine AA carefully avoids any direct reference to future membership perspectives for Ukraine but somewhat diplomatically observes that "the European Union acknowledges the European aspirations of Ukraine and welcomes its European choice." This formulation is somewhat reminiscent of the formula used in the old Europe Agreements with the countries of Central and Eastern Europe. ${ }^{41}$ It does not entail any legal or political commitment towards further enlargement on behalf of the Union. The EU-Ukraine AA is thus not a pre-accession agreement such as the Stabilisation and Association Agreements (SAAs) with the Western Balkan countries, ${ }^{42}$ however, it neither excludes a membership perspective. In this view, the preamble states that "this Agreement shall not prejudice and leaves open future developments in EU-Ukraine relations." In addition, the parties explicitly recognize that "Ukraine as a European country shares a common history and common values with the Member States of the EU and is committed to promoting those values." The parallels with the first sentence of Article 49 TEU are obvious. Moreover, it is noteworthy that several provisions reflect the formulation of the Copenhagen pre-accession criteria. Political criteria such as stability of institutions guaranteeing democracy, the rule of law, human rights and fundamental freedoms are not only defined as "essential elements" of the EU-Ukraine AA,43 they are also an integral part of the established political dialogue ${ }^{44}$ and cooperation in the area of freedom, security and justice. ${ }^{45}$ At the economic level, the establishment of a DCFTA is regarded as an instrument "to complete [Ukraine's] transition into a functioning market economy." 46 Last but not least, the entire agreement is based on Ukraine's commitment to achieve "convergence with the EU in political, economic and legal areas."

40 In a Statement on this Council Decision, the Commission declared that it has mode one proposal for one Decision based on Art. 217 TFEU and, therefore, "disagrees with the addition of legal bases, in particular Article 79(2)(b), with the effect in particular of splitting the Decision."

41 For instance, in the preamble to the EA with Poland the parties recognized "the fact that the final objective of Poland is to become a member of the Community and that this association [...] will help to achieve this objective." In other words, accession was regarded as a clear ambition of the associated states but not as a mutual objective. The SAAs explicitly refer to the Western Balkan countries' status as "a potential candidate for EU membership." Also the Association Agreement with Turkey is conceived to "facilitate the accession of Turkey to the [Union] at a later date."

43 Preamble EU-Ukraine AA.

44 Art. 6 EU-Ukraine AA.

45 Art. 14 EU-Ukraine AA.

46 Art. 1(2)(d) EU-Ukraine AA. 
Nevertheless, the EU-Ukraine AA does not aim at the preparation of Ukraine's accession to the EU but at the establishment of "close and privileged links." ${ }^{\text {" } 7}$ In other words, the key objective of the EU-Ukraine AA is to ensure Ukraine's partial integration in the EU without offering any concrete membership perspective. It is well known that such a process raises significant challenges in terms of the EU acquis export and, in particular, for the uniform interpretation and application of the shared legal framework within legal systems of third countries. ${ }^{48}$ For this purpose, the Association Agreement with Ukraine introduces a reinforced institutional framework, enhanced forms of conditionality and sophisticated mechanisms for legal approximation and dispute settlement which are distinct from other existing models of integration without membership.

\section{A Reinforced Institutional Framework}

The EU-Ukraine AA establishes a multi-level institutional framework that is based on practices of other EU association agreements but bears some considerable novelties. Summit meetings at the highest political level are to take place on an annual basis providing overall guidance for the implementation of the agreement and an opportunity to discuss issues of mutual interest. ${ }^{49}$ This is a confirmation of an already existing practice even though the EU-Ukraine PCA did not include such an explicit provision. A more significant development for the EUUkraine relations is the creation of an Association Council, meeting at the Ministerial level, with decision-making capacities. ${ }^{50}$ The Association Council plays a crucial role in the process of legislative approximation. It operates as a forum for exchange of information on EU and Ukrainian legislative acts and is competent to update or amend the agreement's annexes to keep pace with evolutions in EU law. ${ }^{51}$ An Association Committee with representatives at senior civil servant level assists the Association Council in the performance of its duties. ${ }^{52}$ Moreover, specific sub-committees can be established. ${ }^{53}$ Civil society cooperation forms a specific chapter of the EU-Ukraine AA and aims, amongst others, to ensure a better mutual knowledge and understanding between the parties. ${ }^{54}$ Civil Society institutions are expected to play a role in the field of trade and sustainable development ${ }^{55}$ and to be involved in social and cultural dialogues. ${ }^{56}$ This civil society component reflects its importance within the framework of the

47 Art. 1(2)(a) EU-Ukraine AA.

48 Łazowski, supra note 7,1433 .

49 Art. 46o EU-Ukraine AA.

$5^{\circ}$ Under the EU-Ukraine PCA there was only a Co-operation Council which could only adopt recommendations but no binding decisions. Art. 463 EU-Ukraine AA. Specific procedures are applicable with regard to legislative approximation in areas related to the DCFTA. Art. 464 EU-Ukraine AA. 
Eastern Partnership and complements the multilateral Civil Society Forum that was established after the 2009 Prague Eastern Partnership Summit.

\section{Enhanced Conditionality in the EU-Ukraine AA}

Conditionality is one of the key strategic tools of the ENP and it is, therefore, no surprise that this instrument also occupies a prominent place in the EU-Ukraine AA. Two different forms of conditionality can be distinguished. On the one hand, the Agreement includes several provisions related to Ukraine's commitment to the common European values of democracy, rule of law and respect for human rights and fundamental freedoms ("common values" conditionality). On the other hand, the part on the DCFTA is based on an explicit "market access" conditionality implying that Ukraine will only be granted additional access to a section of the EU Internal Market if the EU decides, after a strict monitoring procedure, that Ukraine successfully implemented its legislative approximation commitments. Both forms of conditionality bear some revolutionary features in comparison to other external agreements concluded between the EU and third countries.

\section{Common Values Conditionality}

International agreements concluded on behalf of the EU include standard conditionality clauses. In general, an "essential element clause" defining the core common values of the relationship is combined with a "suspension" clause including a procedure to suspend the agreement in case of violation of those essential elements. Such a mechanism is also included in the EU-Ukraine AA. ${ }^{57}$ Yet, the common values conditionality in the EU-Ukraine AA differs from similar provisions included in, for instance, the SAAs with the Western Balkans. First, in addition to the standard reference to democratic principles, human rights and fundamental freedoms as defined by international legal instruments (Helsinki Final Act, the Charter of Paris for a New Europe, the UN Universal Declaration on Human Rights and the European Convention on Human Rights and Fundamental Freedoms), ${ }^{58}$ a specific reference to human rights and fundamental freedoms is included in Article 6 EU-Ukraine AA on "dialogue and cooperation on domestic reform"59 and in Article 14 EU-Ukraine AA dealing with EU-Ukraine cooperation on justice, freedom and security. Second, the essential elements of the EU-Ukraine AA contain common values that go beyond classical human rights and also include very strong security elements such as the "promotion of respect for the principles of sovereignty and territorial integrity, inviolability of borders and independence, as well as countering the proliferation

57 Art. 2 in conjunction with Art. 478 EU-Ukraine AA.

58 Art. 2 EU-Ukraine AA. The same principles and legal instruments are mentioned in Art. 2 of the SAA with Serbia.

59 This dialogue foresees that the parties "shall cooperate in order to ensure that their internal policies are based on principles common to the parties, in particular, stability and effectiveness of democratic institutions and the rule of law and on respect of human rights and fundamental freedoms." 
of weapons of mass destruction, related materials and their means of delivery." 60 Third, "the principles of free market economy" as well as a list of other issues such as "rule of law, the fight against corruption, the fight against the different forms of transnational organised crime and terrorism, the promotion of sustainable development and effective multilateralism" are not included in the definition of essential elements. ${ }^{61}$ Rather, they are considered to "underpin" the relationship between the parties and are "central to enhancing" this relationship. ${ }^{62}$ In other words, a distinction is made between hard core common values related to fundamental rights and security, and a range of other general principles that are deemed crucial for developing closer relations but which cannot trigger the suspension of the entire agreement. ${ }^{63}$

\section{Market Access Conditionality}

Apart from the more general "common values" conditionality, the EU-Ukraine AA entails a specific form of "market access" conditionality, which is explicitly linked to the process of legislative approximation. Hence, it is one of the specific mechanisms introduced to tackle the challenges of integration without membership. Of particular significance is a far-reaching monitoring of Ukraine's efforts to approximate national legislation to EU law, including aspects of implementation and enforcement. ${ }^{64}$ To facilitate the assessment process, the Ukrainian government is obliged to provide reports to the EU in line with approximation deadlines specified in the Agreement. ${ }^{65}$ In addition to the drafting of progress reports, which is a common practice within the EU's pre-accession strategy and the ENP, the monitoring procedure may include "on-the-spot missions, with the participation of EU institutions, bodies and agencies, non-governmental bodies, supervisory authorities, independent experts and others as needed." 66 Arguably, the latter option is a new and far-reaching instrument introduced precisely to guarantee that legislative approximation goes beyond a formal adaptation of national legislation.

6o Art. 2 EU-Ukraine AA. In comparison, Arts. 2 and 3 of the SAA with Serbia only include full cooperation with the International Criminal Tribunal for the former Yugoslavia (ICTY) and nonproliferation of weapons of mass destruction as essential elements of the agreement. On the other hand, Art. 2 of the SAA includes a general reference to "respect for principles of international law," which is not in Art. 2 of the EU-Ukraine AA.

61 Art. 3 EU-Ukraine AA. In contrast, Art. 2 of the SAA with Serbia includes the principles of the market economy in the list of essential elements.

62 Art. 3 EU-Ukraine AA.

63 Art. 478 EU-Ukraine AA foresees that a suspension of the entire agreement, including the part on Trade and Trade-related measures, is only possible in case of violation of the essential elements or in accordance with the general rules of international law.

64 Art. 475(2) EU-Ukraine AA.

65 Art. 475(2) EU-Ukraine AA.

66 Art. 475(3) EU-Ukraine AA. 


\section{Constitutional Challenges for the Implementation of the EU-Ukraine AA}

After the long and difficult process leading to the signing and conclusion of the EU-Ukraine AA, significant challenges for the effective implementation of this ambitious legal framework need to be addressed. Three issues can be distinguished: the implications of Russia's annexation of Crimea, the status of the EU-Ukraine AA and decisions of the Association Council in the Ukrainian legal system and the potential direct effect of the Agreement in the EU legal order.

\section{The Crimea Question and the Territorial Scope of the EU-Ukraine AA}

The text of the EU-Ukraine AA was already initialed before the Russian annexation of Crimea. ${ }^{67}$ Consequently, this issue and its impact on the territorial scope of application of the EU-Ukraine AA are not addressed in the text of the agreement. Nevertheless, the question has important implications, in particular for the DCFTA part and the determination of the rules of origin. ${ }^{68}$

According to the European Council, the EU "strongly condemns the illegal annexation of Crimea and Sevastopol to the Russian Federation and will not recognize it." ${ }^{69}$ Consequently, it can be argued that products from the Crimea region are by the EU still considered to be goods originating in Ukraine and, therefore, benefit from the preferential trade regime foreseen in the DCFTA or in the EU's autonomous trade preferences. However, in practice, only Russian authorities will be able to issue the relevant origin certificates for products manufactured or processed in Crimea. As confirmed by the Court of Justice, the EU cannot accept the proof of origin issued by authorities other than those designed by name in the relevant (preferential) agreement. ${ }^{70}$ Because there are no competent customs authorities in Crimea to establish the origin of the goods as "Ukrainian," the products de facto cannot, in fact, benefit from preferential treatment of the DCFTA. Meanwhile, the European Council has asked the Commission to evaluate the legal consequences of the annexation of Crimea and to propose economic, trade and financial restrictions regarding Crimea for rapid implementation. On a proposal by the Commission, the Council made a first step in this regard on 23 June 2014 when it prohibited the import of goods originating in Crimea or Sevastopol into the EU. However, goods originating in Crimea or Sevastopol, which have been granted a certificate of origin by Ukrainian authorities,

67 On 18 March 2014, the Treaty on Accession of the Republic of Crimea to Russia was signed between representatives of Crimea and the Russian Federation after a referendum was held in Crimea on 16 March 2014.

68 It is noteworthy that EU preferential trade agreements with other "contested" territories such as the Turkish Republic of Northern Cyprus or the Israeli settlements in the West Bank already triggered discussion on the territorial scope of these agreements and the application of their rules of origin. See: Case C-432/92, Anastasiou (Pissouri) [1994] ECR I-3087; Case C-386/o8, Brita GmbH, [2010] ECR I-01289.

69 European Council Conclusion, Brussels, 20/21 March 2014, EUCO 7/1/14, para. 29.

Court of Justice, Case C-432/92, Anastasiou (Pissouri) [1994] ECR I-3087. 
may still be imported into the EU. ${ }^{71}$ Moreover, in the Final Act between the EU and Ukraine as regards the EU-Ukraine AA, the parties agree that the Agreement:

"shall apply to the entire territory of Ukraine as recognized under international law and shall engage in consultations with a view to determine the effects of the Agreement with regard to the illegally annexed territory of the Autonomous Republic of Crimea and the City of Sevastopol in which the Ukrainian Government currently does not exercise effective control."72

Ukraine regards the territory of Crimea as "temporary occupied territory" and continues to consider the Ukrainian Constitution and legal system applicable therein. ${ }^{73}$ It means that residents of Crimea and Sevastopol holding Ukrainian citizenship (and Russian citizenship if it was issued automatically without consent of Ukrainian national) may enjoy rights under the EU-Ukraine AA on the same basis as the Ukrainian nationals. The status of Ukrainian companies established in Crimea and Sevastopol is not defined yet. However, without doubt, a future Law on Implementation of the EU-Ukraine AA must determine the status of Ukrainian nationals and companies residing in Crimea and Sevastopol with regard to application of the EU-Ukraine AA in detail.

\section{The EU-Ukraine Association Agreement and the Ukrainian Constitution}

The implementation of the EU-Ukraine AA creates important challenges from the perspective of Ukrainian constitutional law. According to Article 9 of the 1996 Constitution:

International treaties that are in force, agreed to be binding by the Verkhovna Rada [Parliament] of Ukraine, are part of the national legislation of Ukraine.

The conclusion of international treaties that contravene the Constitution of Ukraine is possible only after introducing relevant amendments to the Constitution of Ukraine. ${ }^{74}$

This provision implies that, after ratification, the EU-Ukraine AA will be an integral part of the Ukrainian legal order. Pursuant to Article 19(2) of the Law of Ukraine "On International Treaties

71 Council of the European Union, "EU prohibits imports of goods from Crimea and Sevastopol," Press 346, June 23, 2014.

72 Final Act between the European Union and the European Atomic Energy Community and their Member States, of the one part, and Ukraine, of the other part, as regards the Association Agreement, 27 June 2014, OJ, 2014, L 161.

73 Law of Ukraine "On Protection of Rights and Freedoms of Nationals and Legal Regime on the Temporary Occupied Territory of Ukraine” of 15 April 2014, No. 1207-VII.

74 Full text in English is available on the website of the Ukrainian Constitutional Court, accessed December 30, 2014, http://www.ccu.gov.ua/en. 
of Ukraine," it will enjoy priority over conflicting national legislation..$^{75}$ However, this is not the case if there is a conflict with the provisions of the Ukrainian Constitution. In this respect, it is noteworthy that some of the EU-Ukraine AA provisions impose commitments on Ukraine that directly contradict the national Constitution. For instance, Article 8 EU-Ukraine AA binds Ukraine to ratify and implement the Rome Statute on the International Criminal Court and its related instruments. However, in a judgment of 11 July 2001, the Constitutional Court of Ukraine concluded that several provisions of the Rome Statute were not in conformity with the national Constitution. ${ }^{76}$ Consequently, the ratification of the Rome Statute on the International Criminal Court by the Verkhovna Rada is only possible after a constitutional revision and a positive ruling of the Constitutional Court. ${ }^{77}$ Another issue concerns the approximation of Ukrainian legislation to the dynamic EU acquis. Taking into account that Ukrainian institutions are not involved in the decision-making process of EU legislation, the question arises to what extent this can be reconciled with fundamental constitutional principles such as legality and sovereignty. ${ }^{78}$

One of the major problems to be solved in the course of implementation and application of the EU-Ukraine AA is the lack of direct enforceability of international agreements in the Ukrainian legal order. ${ }^{79}$ In particular, the question arises how binding decisions of the Association Council will be applied in Ukraine. The Ukrainian legal system has never experienced the necessity to apply binding decisions of institutions established under the framework of an international agreement. Therefore, the adoption of a special implementation law clarifying the implications of the EUUkraine AA for the application and interpretation of national legislation is a crucial prerequisite

75 Article 19(2) of Law of Ukraine "On International Treaties of Ukraine" of 29 June 2004, No. 19o6-IV provides that "If duly ratified international treaty of Ukraine contains other rules then relevant national legal act of Ukraine rules of the respective international treaty should be applied."

Ruling of the Constitutional Court of Ukraine on compatibility of the Constitution of Ukraine to the Rome Statute of the International Criminal Court of 11 July 2001, No. 1-35/2001. In particular, the Constitutional Court of Ukraine found the reference in Article 1 of the Rome Statute that "[the Court] shall be complementary to national criminal jurisdictions" as contrary to provisions of the Constitution of Ukraine which prohibit delegation of judicial powers to other bodies then the Ukrainian courts and establishment of new courts that are not provided in the Constitution.

77 Interim President of Ukraine Oleksandr Turchynov asked the Constitutional Court of Ukraine to rule on constituonality of ratification of the Rome Statute of the International Criminal Court on 22 May 2014 .

78 Article 5 of the Constitution of Ukraine provides that "The right to determine and change the constitutional order in Ukraine shall belong exclusively to the people and shall not be usurped by the State, its bodies, or officials."

This happens mainly due to: 1 ) the belief that international case law is not relevant to continental law systems; 2) the translation of case law and jurisprudence; 3 ) lack of translation of case law into Ukrainian to help judges adapt their decisions to best European standards. Furthermore, the Verkhovna Rada of Ukraine is not always expedient in solving conflicts between ratified international agreements and national legislation. For more detail see Roman Petrov and Paul Kalinichenko, "The Europeanization of Third Country Judiciaries through the Application of the EU Acquis: The Cases of Russia and Ukraine," International \& Comparative Law Quarterly 60.2 (2011): 325-53. 
to tackle most challenges of legislative approximation. Notably, Ukraine has already gained some experience in ensuring the implementation of international norms after the ratification of the European Convention of Human Rights (ECHR) in 1997. The incorporation of the ensuing obligations took place by means of two laws. The first was a law on ratification of the ECHR wherein Ukraine recognized the jurisdiction of the European Court on Human Rights (ECtHR). ${ }^{80}$ The second was a special law on the application of case law of the ECtHR in Ukraine. It imposed on Ukraine a duty of mandatory and timely execution of all ECtHR judgments. ${ }^{81} \mathrm{In}$ accordance with these laws judgments of the ECtHR are being formally accepted by the national judiciary as sources of law and Ukrainian judges frequently refer to the ECtHR judgments in their decisions. However, the rate of effective application of the ECtHR case law in Ukraine is considered as unsatisfactory and lags far behind other European countries. ${ }^{82}$

\section{Concluding Remarks}

Taking into account the comprehensive nature of the agreement and the underlying conditionality approach, the EU-Ukraine AA occupies, together with the Moldova and Georgia AAs, a unique position within the network of bilateral agreements concluded between the EU and third countries.

It is a truly innovative legal instrument in the EU's external relations practice based on comprehensiveness, complexity and conditionality. The EU-Ukraine AA does not go as far as the EEA Agreement, which extends the entire EU Internal Market acquis to the participating EFTA States on the basis of homogeneity. Yet, in certain specific areas where full internal market treatment is foreseen, such as in several sections on services and establishment, certain arrangements under the EU-Ukraine AA are comparable to the mechanism for legislative approximation under the EEA Agreement. A key difference, of course, is the far-reaching market accession conditionality as foreseen under the EU-Ukraine AA. Based upon a strict monitoring process, apparently inspired by the pre-accession methodology, not only the process of legislative approximation but also — and most importantly — the effective enforcement and implementation of the EU-Ukraine AA is subject to permanent scrutiny. This market access conditionality illustrates that the EU is very cautious to open up its Internal Market for third countries which have a less stable political and economic system than the EEA countries.

As an innovative legal instrument, the EU-Ukraine AA also fundamentally differs from other agreements with the EU's neighboring countries. It creates a single legal framework

80 Law of Ukraine "On Ratification of the European Convention on Human Rights 1950, First Protocol and Protocols No. 2, 4, 7 and 11" of 17 July 1997, No. 475/97-BP. (Please note that here "BP" is printed in Latin letters, however for finding this law at the website of Ukrainian Parliament it shall be entered in Cyrillic.)

81 Law of Ukraine "On Execution of Judgments and Application of Case Law of the European Court of Human Rights" of 23 February 2006, No. 3477-IV.

82 For example see the 7 th Annual Report of the Committee of Ministers, "Supervision of the Execution of Judgments and Decisions of the European Court of Human Rights, 2013," accessed August 30, 2015, http://www.coe.int/t/dghl/monitoring/execution/Source/Publications/CM_annreport2013_en.pdf. 
opposed to the Swiss model of sectoral bilateralism and it is not sector-specific such as the multilateral EnC Treaty or the ECAA. Rather, the EU-Ukraine AA incorporates certain bits and pieces derived from other agreements and policies. Accordingly, it forms a new type of integration without membership, with all legal complexities this entails.

\section{Bibliography}

Gotev, Georgi. "Ukraine Ready to Sign Association Agreement during March EU Summit." Euractiv.com, February 27, 2014. Accessed December 30, 2014. http://www.euractiv.com/ europes-east/ukraine-wants-sign-association-a-news-533818.

Łazowski, Adam. "Enhanced Multilateralism and Enhanced Bilateralism: Integration without Membership in the European Union." Common Market Law Review 45.5 (2008): 1433-58.

Maresceau, Marc. "Les accords d'intégration dans les relations de proximité de l'Union européenne." In Les frontières de l'Union européenne, edited by Claude Blumann, 151-92. Bruxelles: Bruylant, 2013.

Petrov, Roman. "Recent Developments in the Adaptation of Ukrainian Legislation to EU Law." European Foreign Affairs Review 8.1 (2003): 125-41.

Petrov, Roman, and Paul Kalinichenko. "The Europeanization of Third Country Judiciaries through the Application of the EU Acquis: The Cases of Russia and Ukraine." International \& Comparative Law Quarterly 6o.2 (2011): 325-53.

Van Elsuwege, Peter, and Guillaume Van der Loo. "Competing Paths of Regional Economic Integration in the Post-Soviet Space: Legal and Political Dilemmas for Ukraine." Review of Central and East European Law 37 (2012): 421-47.

Van der Loo, Guillaume. "The EU-Ukraine Deep and Comprehensive Free Trade Area: A Coherent Mechanism for Legislative Approximation?" In Legislative Approximation and Application of EU Law in the Eastern Neighbourhood of the European Union. Towards a Common Regulatory Space? edited by Peter Van Elsuwege, Roman Petrov, 63-88. Milton Park, Abingdon, Oxon: Routledge, 2014.

\section{i}

Roman Petrov lectured at Jean Monnet Module in EU law at the Donetsk National University (2001-2004) and conducted post-doctoral research as Max Weber Fellow at the European University Institute (Italy, 2006-2008) and had visiting fellowships at University of Heidelberg (Germany), University of Oxford (UK), University of Ghent (Belgium). Dr. Petrov is founder and first elected President of the Ukrainian European Studies Association (http://jmce.ukma.kiev. ua/uk/uaes) and Head of the Jean Monnet Centre of Excellence in European Studies (http:// jmce.ukma.kiev.ua). Areas of Dr. Petrov's research and teaching include EU Law, EU External Relations Law; Approximation and Harmonisation of Legislation in the EU; Rights of Third Country Nationals in the EU, EU-Ukraine Association, Legal Aspects of Regional Integration in the Post-Soviet Area. Since September 1, 2015 Prof. Dr. Petrov is Head of the Department of International Law at the National University of Kyiv-Mohyla Academy. 
Guillaume Van der Loo is postdoctoral research fellow at the Ghent University. His research focuses on trade issues of EU external relations and association agreements with third countries.

Peter Van Elsuwege is Professor in EU law at the Ghent European Law Institute (GELI) of Ghent University. His research activities essentially focus on the law of EU external relations. Specific attention is devoted to the legal framework of the relations between the European Union and its East European neighbors. He is the author of From Soviet Republics to EU Member States. A Legal and Political Assessment of the Baltic States' Accession to the EU (Brill, 2008) and the co-editor (with Roman Petrov) of Legislative Approximation and Application of EU Law in the Eastern Neighbourhood of the European Union: Towards a Common Regulatory Space? (Routledge, 2014). 